\title{
Gold Foil Figures and Norse Mythology: Fact and Fiction?
}

\section{Margrethe Watt}

Bornholms Museum, Rønne

Gold foil figures (Swedish: guldgubbar) have been established as an archaeological "type" for nearly 300 years and are well known to Scandinavian archaeologists. ${ }^{\mathrm{I}}$ They have also attracted attention from historians and specialists in the history of religion. ${ }^{2}$ As new finds appear from time to time, it seems appropriate to give a short update on some basic facts and to clarify the terminology used in the discussion.

The term "guldgubbe" is here applied to figures which are stamped with a bronze die (patrix) on thin sheets of gold or gold-silver alloys (Fig. 6a). The term "die" is used as a common denominator for figures embossed (stamped) on the same bronze die (die identity).

About $5 \%$ out of a total of more than 3,000 figures are scratched on - or cut out of - thicker gold sheet. Three-dimensional figures are not included in this definition, but are relevant to the iconographic interpretation. In contrast to both bracteates and anthropomorphic figures, which, for example feature on objects decorated in the widespread animal Style I, they are a purely Scandinavian phenomenon.

Gold foil figures are first and foremost associated with large and important settlement sites. ${ }^{3}$ Because the gold content is very variable and the value of the gold negligible, they are unlikely to have been part of a primary economy. Numerically, the vast majority of the figures are found on the island of Bornholm in the southern Baltic (several localities). Single figures dominate in south-eastern

How to cite this book chapter:

Watt, M. 2019. Gold Foil Figures and Norse Mythology: Fact and Fiction?. In: Wikström af Edholm, K., Jackson Rova, P., Nordberg, A., Sundqvist, O. \& Zachrisson, T. (eds.) Myth, Materiality, and Lived Religion: In Merovingian and Viking Scandinavia. Pp. I9I-22I. Stockholm: Stockholm University Press. DOI: https://doi.org/Io.I6993/bay.h. License: CC-BY. 
Scandinavia while gold foils showing two persons dominate on the Danish islands of Fyn and Sjælland as well as further north in Sweden in a stretch from Uppland across to Västra Götaland and in southern and western Norway.

The figures are difficult to date archaeologically as they are rarely found outside the wider context of settlement sites with long continuity; hence there is a considerable risk of chronological "contamination" due to a complex stratigraphy. Unlike many other artefact types, gold foil figures are almost completely absent from grave finds. Traditional dates range from the Late Migration Period to the early Viking Age - a span of 300-400 years. However, based on modern excavation methods, combined with iconographic as well as stylistic analyses, it has become increasingly difficult to uphold some of the late dates (Viking Age). ${ }^{4}$ Stylistic as well as specific iconographic details point to dates in the 6 th and $7^{\text {th }}$ centuries for both single figures and man-woman pairs from southern Scandinavia. As an example, I am convinced that at least three of the figures from Borg in Lofoten off northern Norway may have been imported the long way by sea from places like Sorte Muld, Uppåkra or Lundeborg where stylistically very similar figures are found. The fact that two of the gold foils from Borg were found in a post hole of a large building, dated to the Viking Age, 5 does not preclude a connection to an earlier building phase. The reason for - or significance of - re-deposition in the Viking Age falls outside the scope of this paper. I have deliberately concentrated my effort on the iconographic aspects of the gold foils, and hence abstained from discussing the wider implication of their role in the pre-Christian cult (however important). This is in order to avoid over-simplification of this highly complex issue involving important sites like Helgö, Uppåkra, Sorte Muld and Guldhullet (Bornholm). ${ }^{6}$

Die-identical (or stylistically very similar) figures were almost certainly made within a short span of years. This, of course, does not rule out that some figures could have been handed down as "keepsakes" within a family. But it should be remembered that the majority of gold foil figures are very fragile - many of them with a weight of less than O.I g.

Only exceptionally do we see examples of gold foil figures mounted as pendants or showing wear, in which case the stamped 
figures always have a backing of a thicker bronze or gold sheet. Many figures - particularly from Sorte Muld - had been folded into small packages (possibly for re-melting) - a fact to remember when discussing their significance and use.

Misreading of iconographic details on the tiny gold foils is easy and has in some cases led to odd and even far-fetched interpretations. ${ }^{7}$ Secondary folds or dents in the thin gold foil have not helped. It should be added that none of the gold foils bear inscriptions of any kind.

\section{Die Families}

In the same way Alexandra Pesch has defined a number of die-families for the Migration Period bracteates - based primarily on iconographic similarities, ${ }^{8}$ this can also be done for the guldgubbar (Fig. I). At present, 63 such families are recognised, some
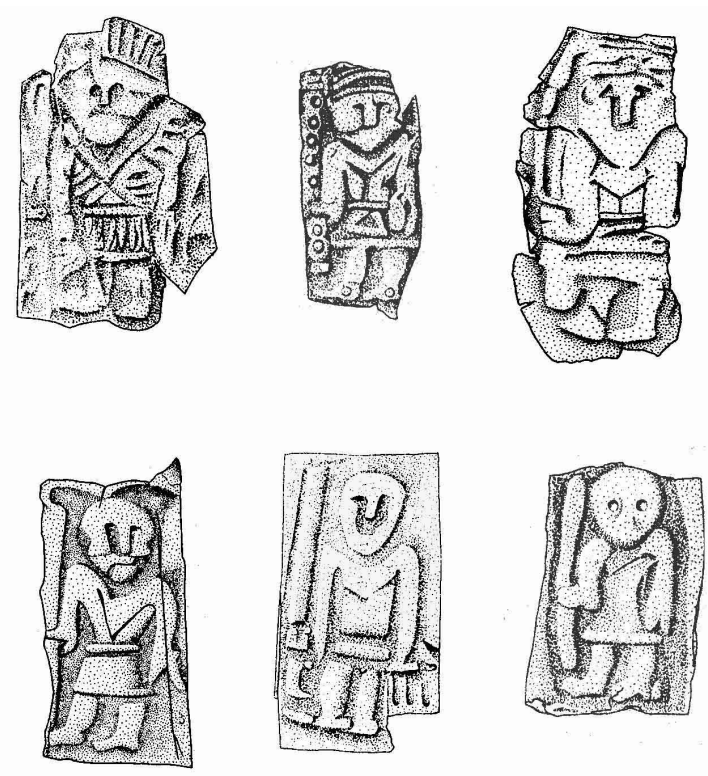

Figure 1. "Die-family" 9, represented at Sorte Muld and Uppåkra. The figures measure from 6 to $9 \mathrm{~mm}$ in height. Drawing: Eva Koch. Copyright: Bornholms Museum: License CC BY-NC-ND. 
of which are very local while others have a wider distribution. ${ }^{9}$ Die links and/or family links as well as stylistic details indicate that some regional variations could be linked to "workshops" or to individual craftsmen.

Stylistic differences and regional variations in iconographic detail point to three major "provinces" (Fig. 2) that are believed to be relevant for the discussion of the political landscape and early state formation in Scandinavia. ${ }^{\circ}$

\section{Iconographic Analysis}

Based on the study of more than 750 different dies and close to Io० individually cut-out or engraved figures, I have registered a number of recurring elements: I. the orientation of individual

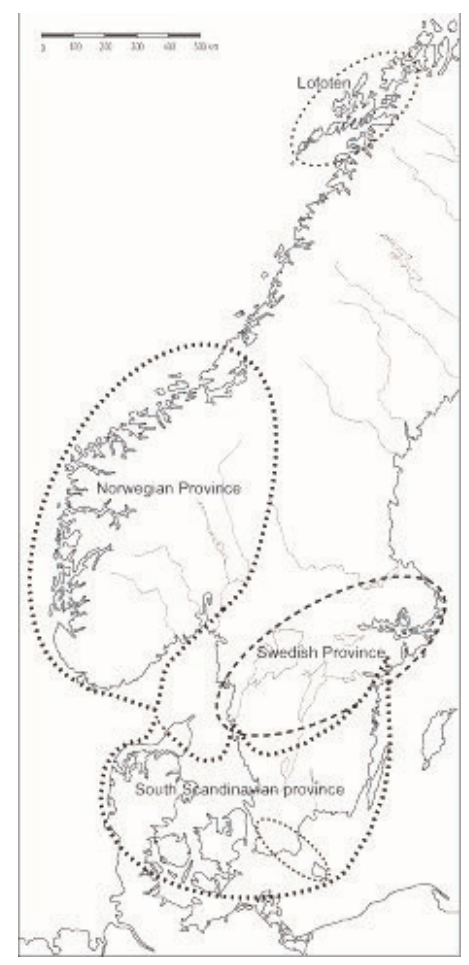

Figure 2. Distribution of gold foil figures. Drawing: M. Watt Copyright: Margrethe Watt 20I I, License: CC BY-NC-ND. 
figures, 2. physiognomy (primary sexual markings), 3. hairstyle, 4. dress, 5. gesture and posture, and 6. attributes or "insignia" (staff/sceptre, drinking horn, etc.).

The considerable number of different dies allows for a statistical approach, and the combination of iconographic elements is the main key to understanding the gold foil figures. Details of dress and hairstyle are crucial for the determination of, for example, rank and sex. Gestures are important to understanding some of the less

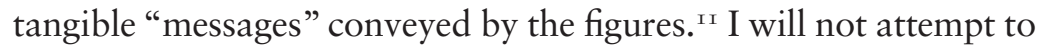
describe or explain all of these but will point to some examples that are - hopefully - relevant to the theme of the conference.

\section{Motif Groups}

The greatest variety is found within the group of single figures from southern Scandinavia, while the appearance and gestures of the widespread man-woman couples is more stereotyped despite numerous minor variations. Hence, the two are treated separately.

The statistical analyses have revealed that the die-families as well as individual dies form a number of motif groups consisting of figures with common iconographic features or a common theme. The most numerous motif-group among the single figures consists of approximately I 80 different dies while some of the minor variations can be counted on one hand (Fig. $3 \mathrm{a}-\mathrm{c}) .^{\mathrm{I2}}$

Within the dominant single-figure motif group, the most detailed male figures display a dress of kaftan-type and a variety of insignia (e.g. staff, neck rings and arm rings) which have a bearing on social status and function in society. These figures have their closest parallels on the helmet plates found in the "royal" burials in Vendel, Valsgärde, Uppsala (Uppland) and Sutton Hoo (England). ${ }^{\text {'3 }}$

Similar "status indicators" are seen on many of the detailed female figures. Judging from fragments of textile and jewellery from contemporary burials, they depict a dress code that had become established among the Germanic elite from the $6^{\text {th }}$ century onwards. ${ }^{14}$ Despite the fact that each of the motif-groups also includes figures and figure types which are highly simplified, they still form recognisable stereotypes (Fig. $3 \mathrm{c}$ ). 

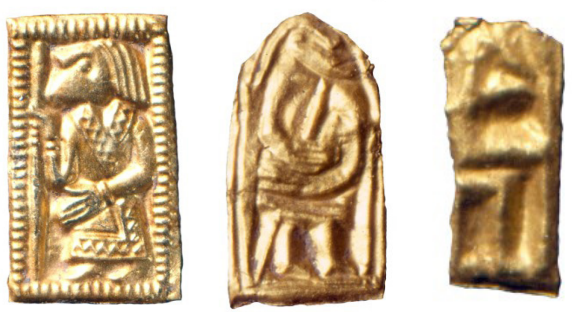

Figure 3a-c. Typical male figures from the motif-groups $\mathrm{A}_{\mathrm{I}}-\mathrm{A}_{4}$, all carrying a long staff. Sorte Muld. Photographer: Kit Weiss (a-b); Lennart Larsen (c). Copyright: Bornholms Museum: License CC BY-NC-ND.

The man-woman pairs form one single motif group with small mostly regional variations in dress and gesture. Despite the fact that individual figures may measure only $6-8 \mathrm{~mm}$, some still show a surprising amount of detail.

\section{Discussion: Historical and Political Backdrop}

Few written sources provide direct or indirect information about political or religious conditions in Scandinavia at the time of the production and use of the gold foil figures. Procopius (500-565) refers to kings who - allegedly - had contacts with Theoderic in Ravenna. ${ }^{\mathrm{I}}$ Both Jordanes (ca. 550) and the later Origo gentes langobardorum (643) - in their genealogies - also draw lines back to Scandinavia in an attempt to establish a divine origin for their royal lineage. ${ }^{16}$

Abundant archaeological material from both settlements and burials, not least on Bornholm, in Skåne and in Uppland, show that the Scandinavian "elite" was aware of the political developments in $6^{\text {th }}$ and $7^{\text {th }}$ century Continental Europe, and even appear to have imitated the Frankish concept of Gefolgschaft. ${ }^{17}$

Gregory of Tours (538-594), who is an important source for the relationship between Christians and pagans in the $6^{\text {th }}$ century, makes no mention of the pre-Christian cult in southern Scandinavia. It also seems inevitable that news of the spreading Christianity and the ensuing religious conflicts should have filtered through to the pagan South Scandinavian elite. ${ }^{8}$ 
However, there are recent finds from a locality on Bornholm ("Guldhullet") of female figures, including gold statuettes, some of which have strong sexual connotations, suggesting the survival of an old fertility cult. ${ }^{19}$ This combination of gold foils and small three-dimensional figurines forms a marked contrast to the ideals of the Gefolgschaftskultur with its warlords and petty kings seen in larger central places like Sorte Muld and Uppåkra.

\section{Iconography and Myth}

You may guess already from the title of this paper that I have certain reservations when it comes to identifying particular figures or motif groups with named mythological characters. Similar reservations have been expressed at intervals by others. ${ }^{20}$ Archaeologists are trained to look at human beings through objects and faint structures in the soil, while colleagues who have studied history of religion are schooled to analyse the development of human relationships with the "otherworld" ${ }^{21}$ When trying to interpret the pictorial content of the gold foils, you constantly find yourself in the challenging position of having to cross the boundaries into other specialist domains with different research traditions.

Understanding Late Antique pictorial language is one thing, but transferring this "understanding" to pre-Christian images is quite another. Here you are constantly faced with the dilemma of whether or not similar iconographic "language" reflects similar meaning when comparing the images of a pagan polytheistic cult on one side with $6^{\text {th }}$ century Christianity on the other. In spite of this, I find contemporary written sources and traditions on the Continent - at least in principle - to be a safer point of departure for the interpretation of the imagery on the gold foils, than extrapolating "backwards" - sometimes several hundred years from the Late Viking Age or the Middle Ages, however tempting this may be.

As an extension of his work on the Migration Period gold bracteates, the German historian Karl Hauck attempted to name certain types of gold foil figures as the natural extension of his work with the figures on the slightly older bracteates, some of which bear an unmistakable resemblance to the gold foils. Rather 
than entering into a complex discussion of specific gods or other named characters, I prefer, in this paper, just to look at the general concept as expressed in the iconographic details.

As indicated earlier all the different dies can be placed in one of the main motif groups - or alternatively in one of the groups of less common variants. In this paper, I have chosen four examples.

\section{The Concept of "Warlord" or "King Among the Gods" (Fig. 3 a-c)}

This numerically dominant group (with approximately I 80 different dies) is first and foremost seen as a reflection of the $6^{\text {th }}$ and $7^{\text {th }}$ century continental Gefolgschaftskultur also represented in contemporary aristocratic and royal burials. The fact that many figures within this motif-group are extremely stylised (Fig. 3c) suggests that they represent a well-established iconographic concept. The main dilemma is that in both Late Antique and Early Medieval iconography renderings of "king" and "god" are almost indistinguishable. Hence, at present, I do not feel comfortable attaching names to specific figures within this group, although arguments have been put forward for identifying gold foils of this type with Pórr. ${ }^{22}$

The vast majority of figures belonging to this motif-group is concentrated at the two important central sites of Sorte Muld and Uppåkra, the latter associated with the "cult building". The combined archaeological material from both sites shows strong and widespread "international" connections. The figures in this motif group suggest the existence of some form of Sakralkönigtum in southern Scandinavia in the $6^{\text {th }}$ and $7^{\text {th }}$ centuries. But the issue is complex, as southern Scandinavia falls into the gap between Continental sources, linguistic evidence and later Norse tradition. ${ }^{23}$

\section{2. "The Seer"}

A small "family" of gold foils shows a male figure with a clearly accentuated thumb placed in the mouth (Fig. 4 a-b). This seemingly odd gesture has forerunners in the Late Migration Period 


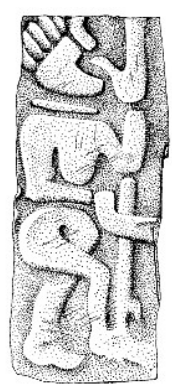

a

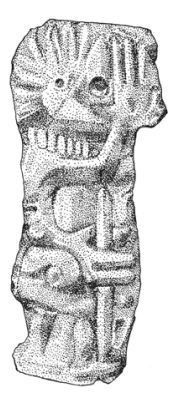

b

Figure 4a-b. "The seer's thumb" shown by two figures from Sorte Muld (a) and Uppåkra (b). "Die-family" 22. The figures measure I 8-19 mm in height. Drawing: Eva Koch (a); M. Watt (b). Copyright: Bornholms Museum: License CC BY-NC-ND.

ornamentation "Style I" as well as on gold bracteates; as far as I am aware, it is unknown in either Roman or Byzantine iconography.

Hilda Ellis Davidsson has convincingly interpreted this gesture, which appears sporadically in parts of northern and western Europe, as illustrating the concept of "the seer's thumb", substantiated in Celtic Britain and Ireland in myths connected with Finn and Taliesin. ${ }^{24}$

I am only aware of a couple of examples where this particular gesture occurs in a clearly Christian context, namely a picture stone from Drumhallagh, Donegal (Ireland), dated to the $7^{\text {th }}$ or $8^{\text {th }}$ century and a $6^{\text {th }}$ century belt buckle of Burgundian type (eastern France/Switzerland), belonging to a group known in the archaeological literature as "prophet buckles" (Fig. 5). In Viking Age Britain and Scandinavia, the gesture is associated with the Sigurd myth.

The gold foil figures belonging to this family also carry a (short) staff - or "wand" - and are shown with their legs crossed in the same manner as on certain gold bracteates. ${ }^{25}$ The posture occurs sporadically throughout the Germanic area and may have supernatural and apotropaic undertones. ${ }^{26}$

The iconographic details on this small family of gold foil figures seem to point to someone with special powers - including the ability to see into the future. This ability is shared whether applied 


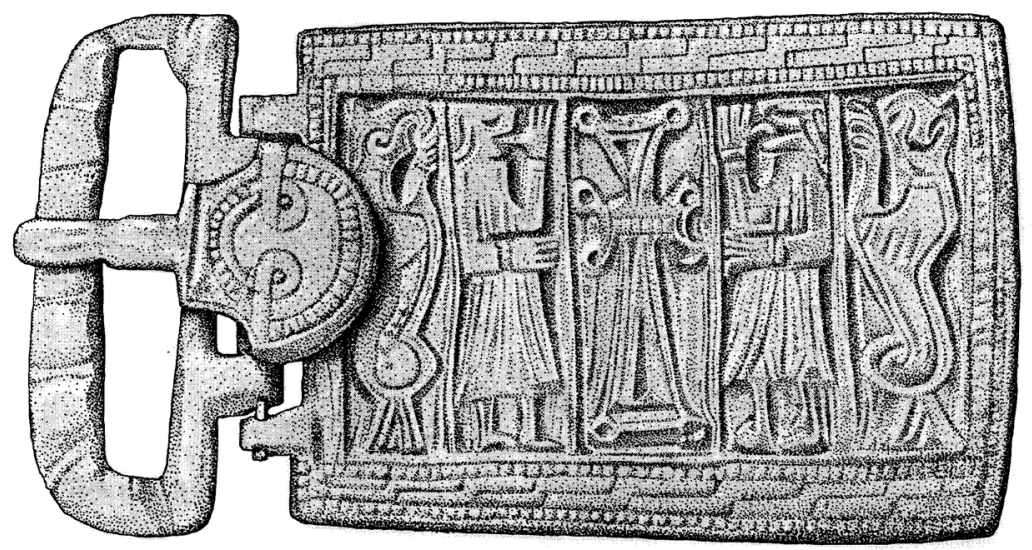

Figure 5. Belt buckle of the so-called "prophet-type" from Eschallens-lesCondemines, Switzerland ( $6^{\text {th }}$ century). The two figures, facing a large cross and flanked by "beasts", show the "seer's gesture". Drawn by M. Watt from a photograph in Haldimann \& Steiner I 996. Licence: CC BY-ND.

to Christian prophets, pagan "soothsayers", Celtic heroes or powerful deities such as Óðinn in his capacity of "seer".

\section{3. "The Seeress"}

Attempting to identify the single female gold foil figures with named characters known from Norse mythology takes you into the sphere of the intangible and leaves you with different options, each of which has been discussed repeatedly in the literature: "Lady of the Mead Hall" (carrying a drinking vessel), Freyja who possessed magic, which she - according to the myths - brought with her from the Vanir gods, Valkyries - greeting the fallen heroes with a mead-horn on their arrival in Valhọll (the latter obviously inspired by the popular interpretation of the so-called "adventus-motif" on the Gotland picture stones). Among other options are the Volvir - and even nornir ("Women of Destiny"). ${ }^{27}$ No doubt, cases can be made for them all; so, we need to look for new details.

Within the group of single female figures, two dies, Uppåkra (U. 4469) and Bornholm ("Melle-I"), are equipped with an 
unusual combination of hand-held attributes (Fig. 6 a-b). The well preserved (possibly even unused) bronze die from Uppåkra (Fig. 6a) shows a woman who (besides the drinking horn) holds a short downward branching object as well as a short slender staff/"wand" (seen below the drinking horn).

Parallels to this combination of attributes are few and far between - and also staggered in time. Iconographically closest is a figure on the well-known picture stone from Gotland, AlskogTjängvide I. Here the woman holds - not just a drinking horn in one hand - but an additional branching object in the other. The stone belongs to Sune Lindqvist's groups C-D, now regarded as contemporary and dated to the $9^{\text {th }}$ and $10^{\text {th }}$ centuries. ${ }^{28}$

The gold foil figure "Melle-I" (Fig. 6b) holds what may be interpreted as a staff(?) with short downturned "side-twigs" (seen below the beaker or drinking horn). Though slightly different in appearance, it may well have the same symbolic content. ${ }^{29}$ An example of the ambiguity that characterises many of the gold foil figures is a unique en-face figure (Sorte Muld-259) seen holding

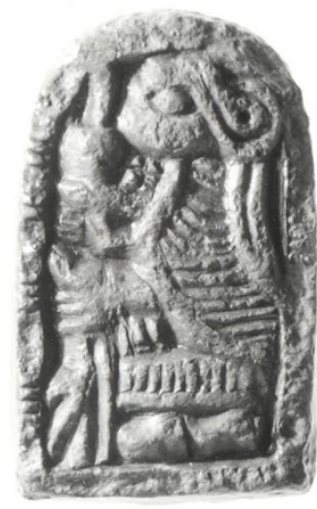

a

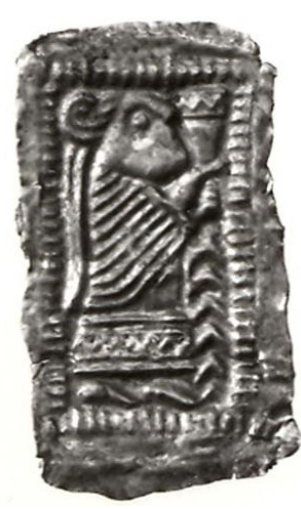

b

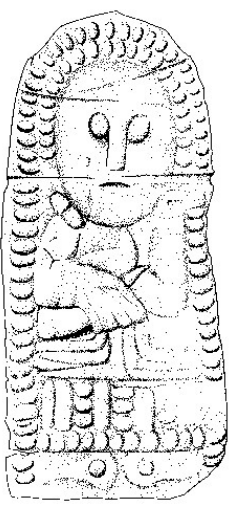

c

Figure 6a-c. "Seeresses". a: Bronze die (patrix) from Uppåkra (Skåne). The figure carries a drinking horn, a downward-branching "staff” besides a short thin staff or "wand"(?); b: gold foil figure "Melle-I", Bornholm, with drinking vessel (beaker) and a "wand"(?) with short side branches; c: Gold foil figure from Sorte Muld (die 259), Bornholm, with an "empty” drinking horn, lying on its side. The figures measure from I 8 to $23 \mathrm{~mm}$ in height. Photo: B. Almgren (a); Nationalmuseet, København (b). Drawing: Eva Koch (c). Copyright: Bornholms Museum: License CC BY-NC-ND. 
an obviously empty(!) drinking horn - marked by the fact that it is lying on its side (Fig. 6c). Who drank the contents - the guests in the mead hall or the woman holding the empty horn (with a "magic" potion)?

The combination of the drinking horn with other "identification tags" (the "potion", the "wand" and branching staff) suggests that these figures could be associated, not just with supernatural powers, but more specifically with prophesy or magic.

It is well known that Tacitus refers to Germanic women with prophetic gifts or powers, and in his Historiae (IV:6I, 65) makes specific mention of a woman Veleda who appears to have played an important part in the Batavi-war. ${ }^{3 \circ}$ Several generations later, written sources also mention pagan seers and witches, who became a persistent "stone in the shoe" for the Christian Church. ${ }^{31}$ According to the roughly contemporary Germanic leges, consulting such "infamous" women was punishable. ${ }^{32}$ Even long after large parts of the Germanic area had converted to Christianity, it still seemed to have been necessary to legislate against "powerful women", who were obviously still regarded as a threat - not just to the church but to society as a whole.

Although few in numbers, I believe that this small group of gold foils is important for understanding the $6^{\text {th }}$ century beliefs and cult in South Scandinavia, as token offerings connected with the wish to foretell (or maybe even influence) the future. ${ }^{33}$ However, instead of naming the figures, I prefer to put the emphasis on the concept of prophesy.

Strangely common to the "seer" and "seeress" figures are the very small numbers in which they occur compared to the large number of other figures. Why this is so is a question I cannot answer.

\section{4. "The Legally Binding Marriage"}

The last motif-group that I wish to comment on shows a man and a woman facing each other. In contrast to the distribution of the single figures, this group occurs throughout Scandinavia and dominates the material in the Swedish and Norwegian "provinces" (Fig. 2). Common to all variations is some degree 
of physical contact, ranging from an embrace to a light touch (Fig. 7).

In several works Gro Steinsland has connected the motif with hieros gamos, and Gerðr and Freyr as the mythical founders of the Ynglinga dynasty, based on the story from Skirnismál. In a work from 1997 she similarly associates the man-woman pairs with Óðinn and Skaði as founders of the Ladejarl dynasty - tying it to the later Norwegian tradition surrounding the "Pillars of the High Seat". ${ }^{34}$ She also points to the element of fate - in this case the conflict between gods and giants - affecting the future of the royal lineage. Her theories illustrate both the difficulties and complexity of deciphering a motif when stretching an archaeological/ iconographic material to the breaking point.

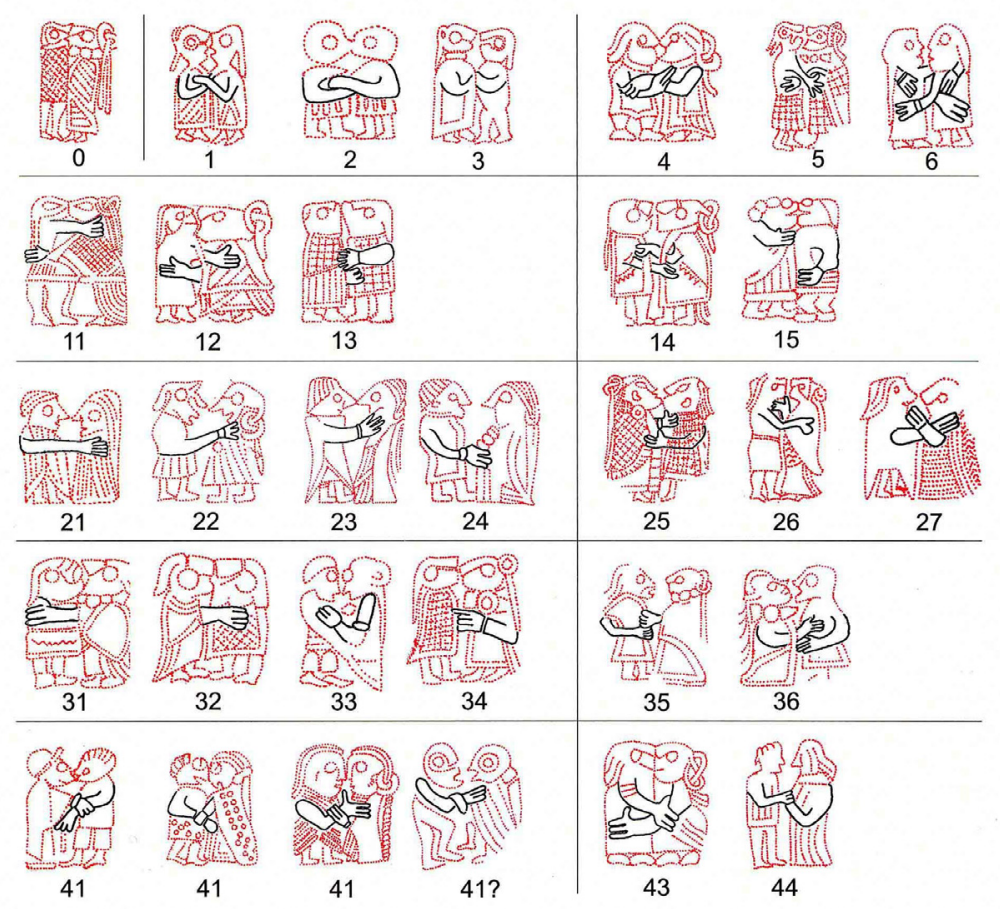

Figure 7. Regional and local variations registered on man-woman gold foil figures. Drawing: M. Watt. Copyright: Margrethe Watt, License: CC-BY-NC-ND. 
Both Roman and not least "Germanic" legal practise mention rules for giving hands or touching each other. ${ }^{35}$ Social, economic and political interests among the Germanic elite required legally binding marriages and betrothals. Rudolf Simek addressed this question some years ago in relation to the man-woman gold foils. ${ }^{36}$ His view, with which I agree, is that the gestures shown by the well-dressed man-woman pairs represent the important visible sign of a formal and legally binding ceremony (the Mundrmarriage). Despite minor regional variations, I believe that the range (Fig. 7) reflects a widespread tradition, but will not attempt to identify the figure-type with named mythological characters certainly not Gerðr and Freyr whose union (according to "Germanic law") would be regarded as an unacceptable common law marriage.

\section{Conclusion}

The aim of this paper is to give an impression of the complexity of the pictorial language shown on the tiny gold foil figures and point out possible pitfalls, whether you approach the material from the post-Roman European Continent or from later Norse literature and mythology. I realise that the few examples I have chosen leave many options which are impossible to discuss fully in a short paper.

Religion and cult practises are basically resilient, but must first and foremost be expected to echo socio-political changes at any given time. It is my belief that the gold foils reflect the establishment of petty kingdoms throughout the Germanic area towards the end of the Migration Period. This almost certainly resulted in a centralisation of the cult practise and introduction of new myths (including additions to the pantheon). ${ }^{37}$

\section{Notes}

I. Melle I725; Sjöborg I79I; Mackeprang I943; Watt I992; 2004; 20I $5 \mathrm{a}, \mathrm{b}$.

2. E.g. Hauck I992; Steinsland I989. 
3. Adamsen et al. 2008.

4. Lamm 2004; Watt 20I 5 a:I 53 ; Watt forthcoming.

5. E.g. Stamsø Munch 2003.

6. Nielsen \& Watt 2019.

7. Watt forthcoming.

8. Pesch 2007.

9. Watt forthcoming.

Io. Cf. Høilund Nielsen I99I; Jørgensen I99I; Helgesson 2002.

II. Watt 2007; 20I 5a-b.

I2. For diagrams showing all motif-groups see Watt 20I 5 a or Watt 20I 5 b.

I3. Stolpe \& Arne I9I2; Bruce-Mitford I978; Hauck I98 I.

I4. Watt 20II; Mannering 2006:2I3; Mannering 2017.

I 5. Künzl 2008:97.

I6. Hedeager I996; 1997.

I7. Nørgård Jørgensen I 999:I 56.

I8. von Padberg 201 I:606.

I9. Watt 20I 5 b:I 88 .

20. E.g. Price 2006.

2I. E.g. Helmbrecht 2015 .

22. Hauck I993:420.

23. E.g. Sundqvist 2004:279.

24. Ellis Davidsson I989; MacKillop 2005:225. The gesture should not be confused with the dextera elata - the raised right hand - seen on, for example, imperial coins and medals.

25. Hauck 1992, Fig. 60 \& 6I; Pesch 2007:I35, "Formularfamilie Bıо”.

26. Schmidt-Wiegand I998:503. 
27. E.g. Enright I988; Simek I993; 2002.

28. Lindqvist I942, Taf. 57; Imer 2012.

29. Other examples of female figures holding a branching staff or are known from both barbarian imitations of $2^{\text {nd }}$ century Roman coins (Bursche 2009) and from an imitation medallion from Aneby (Småland) (Ikonographischer Katalog, no. I4). On a Viking Age picture stone from Kirk Michael on the Isle of Man a woman dressed in a long garment is seen holding a staff with "leaves" at the upper end and a branching "root" at the other. The latter has been interpreted as a Volva (Penz et al. 2009, Fig. I3).

30. Simek 1993:36; Reichert 1995:502.

3I. Gregory of Tours: Historia Francorum V:I4.

32. E.g. Pactus Leges Salicae (6 ${ }^{\text {th }}$ century):XIX, LIV; Lombard Laws of Luitprand ( $\mathrm{AD}$ 727):84-85.

33. Watt, forthcoming.

34. Steinsland I989; 1997.

35. Schmidt-Wiegand I99I; I992.

36. Simek 2002.

37. Watt 20I 5 b.

\section{References}

\section{Primary sources}

Gregory of Tours, Historia Francorum. Thorpe, L. I974. Gregory of Tours. The History of the Franks. Translated by L. Thorpe. London: Penguin Classics.

Lombard Laws. Fischer Drew, Katherine. I991. Lombard Laws. Translated and Edited by Katherine Fischer Drew. Philadelphia: University of Pennsylvania Press.

Pactus leges Salicae. Lex Salica. Fischer Drew, Katherine. I99I. The Laws of the Salian Franks. Translated and with an Introduction by Katherine Fischer Drew. Philadelphia: University of Pennsylvania Press. 


\section{Secondary literature}

Adamsen, C. et al. (eds.). 2008. Sorte Muld. Wormianum, Kulturarvsstyrelsen. Kulturarvsstyrelsen (English language edition 2009 - Sorte Muld. Wealth, Power and Religion at an Iron Age Central Settlement on Bornholm). Rønne: Bornholms Museum.

Bruce-Mitford, R.L.S. 1978. The Sutton Hoo Ship-Burial II. Arm and Armour and Regalia. London: British Museum.

Bursche, A. 2009. Coins. In L. Boye \& U. Lund Hansen (eds.). Wealth and Prestige. An Analysis of Rich Graves from Late Roman Iron Age on Eastern Zealand. Studier I Astronomi. Nyere Tid. Arkæologi 2. Denmark: Kroppedal, I 85-I92.

Ellis Davidsson, H. I989. The Seer's Thumb. In H. E. Davidsson (ed.). The Seer in Celtic and other Traditions. Edinburgh: Donald, 66-78.

Enright, M. J. I988. Lady with a Mead-Cup. Ritual, Group Cohesion and Hierarchy in the Germanic Warband. In Frühmittelalterliche Studien 22, 170-203.

Haldimann, M.-A. \& Steiner, L. I996. Les céramiques funéraires du haut Moyen Age en terre vaudoise. In Jahrbuch der Schweizerischen Gesellschaft für Ur- und Frühgeschichte 79, I43-193.

Hauck, K. I98 I. Die bildliche Wiedergabe von Götter- und Heldenwaffen im Norden seit der Wölkerwanderungszeit. In R. Schmidt-Wiegand (ed.). Arbeiten zur Frühmittelalterforschung I. Wörter und Sachen im Licht der Bezeichnungsforschung, Berlin \& New York: Walter de Gruyter, I69-269.

Hauck, K. I992. Frühmittelalterliche Bildüberlieferung und der organisierte Kult. In K. Hauck (ed.). Der historische Horizont der Götterbild-Amulette aus der Übergangsepoche von der Spätantike zum frühen Mittelalter. Abhandlungen der Akademie der Wissenschaften in Göttingen, Philologisch-Historische Klasse, Dritte Folge, 433-574.

Hauck, K. I993. Die bremische Überlieferung zur Götter-Dreiheit Altuppsalas und die bornholmische Goldfolien aus Sorte Muld. In Frühmittelalterliche Studien 27 Berlin \& New York, 409-479. 
Hedeager, L. I996. Myter og materiel kultur. Den nordiske oprindelsesmyte i det tidligt kristne Europa. In TOR 28, 2 I7-234.

Hedeager, L. 1997. Skygger af en anden virkelighed. Oldnordiske myter. København: Samleren.

Helgesson, B. 2002. Järnålderns Skåne. Sambälle, centra och regioner. Uppåkrastudier 5. Acta Archaeologica Lundensia. Stockholm: Almqvist \& Wiksell.

Helmbrecht, M. 20I 5. Bild und Bildträger während der Vendelzeit. Probleme und Möglichkeiten der Deutung von Bildern aus einer Kultur mit mündlicher Überlieferung. In Heizmann \& S. Oehrl (eds). Bilddenkmäler zur germanischen Götter- und Heldensage. Ergänzungsbände zum Reallexikon der Germanischen Altertumskunde 9I, I 8I-2 I 8 .

Høilund Nielsen, K. I99 I. Centrum og periferi i 6.-8. årh. Territoriale studier af dyrestil og kvindesmykker i yngre germansk jernalder i Syd- og Østskandinavien. In P. Mortensen \& B. M. Rasmussen (eds). Fra Stamme til Stat i Danmark. 2: Høvdingesamfund og Kongemagt. Jysk Arkæologisk Selskabs Skrifter 22(2), I 27-I 53.

Ikonographischer Katalog: Axboe M. et al. (eds). 1985-89. Die Goldbrakteaten der Völkerwanderungszeit. Ikonographischer Katalog I-3. Münstersche Mittelalterschriften 24/I-3. München: Wilhelm Fink Verlag.

Imer, L.M. 20I2. The Viking Period Gotlandic Picture Stones. A Chronological Revision. In Gotländskt Arkiv 84, I I 5-I I 8.

Jørgensen, L. I99I. Våbengrave og krigeraristokrati. Etableringen af en centralmagt på Bornholm i det 6.-8. årh. e. Kr. In P. Mortensen \& B. M. Rasmussen (eds). Fra Stamme til stat $i$ Danmark 2. Høvdingesamfund og Kongemagt. Jysk Arkæologisk Selskabs Skrifter 22(2), I09-I 24 .

Künzl, E. 2008. Die Germanen. Geheimnisvolle Völker aus dem Norden. Stuttgart: Theiss.

Lamm, J.P. 2004. Figural Gold Foils Found in Sweden. A Study Based on the Discoveries from Helgö. In H. Clarke \& K. Lamm (eds). Excavations at Helgö XVI. Exotic and Sacral Finds from 
Helgö. Stockholm: Kungl. Vitterhets Historie och Antikvitets Akademien, 4I-I42.

Lindqvist, S. I942. Gotlands Bildsteine II. Stockholm.

Mackeprang, M.B. I943. Om de såkaldte 'guldgubber'. In Fra Nationalmuseets Arbejdsmark I943, 69-76.

MacKillop, J. 2005. Myths and Legends of the Celts. London: Penguin Books.

Mannering, U. 2006. Billeder af dragt. En analyse af påkloedte figurer fra yngre jernalder i Skandinavien. Ph.D. diss. København: Københavns Universitet.

Mannering, U. 20I7. Iconic Costumes. Scandinavian Late Iron Age Costume Iconography. Oxford: Oxbow Books.

Melle, I. A. I725. Commentatiuncula de simulacris aureis, quae in Boringholmia Maris Balthici insula, agris eruuntur. Lübeck, Typis Io. Nicolai Thvnii.

Nielsen, F.O. \& Watt, M. 2019. Acta Archaeologica 89, 77-89.

Nørgård Jørgensen, A. I999. Waffen und Gräber. Typologische und chronologische Studien zu Skandinavische Waffengräbern 520/30 bis 900 n.Chr. In Nordiske Fortidsminder. Serie B I7.

Padberg, L. von 20 I I. Reaktionsformen des Polytheismus im Norden af die Expansion des Christentums im Spiegel der Goldbrakteaten. In W. Heizmann \& M. Axboe (eds). Die Goldbrakteaten der Völkerwanderungszeit. Auswertung und Neufunde. Ergänzungsbände zum Reallexikon der Germanischen Altertumskunde 40. Berlin, New York: De Gruyter, 603-634.

Pentz, P. et al. 2009. Kong Haralds vølve. In Nationalmuseets Arbejdsmark 2009, 2I 5-23I.

Pesch, A. 2007. Die Goldbrakteaten der Völkerwanderungszeit. Thema und Variation. In Ergänzungsbände zum Reallexikon der Germanischen Altertumskunde 36. Berlin, New York: De Gruyter.

Price, N. 2006. What's in a Name? An Archaeological Identity Crisis for the Norse Gods (and Some of their Friends). In A. Andrén et al. 
(eds.). Old Norse Religion in Long-Term Perspectives. Origins, Changes, and Interactions. An international Conference in Lund, Sweden, June 3-7, 2004. Vägar till Midgård 8. Lund: Nordic Academic Press, I79-I 83 .

Reichert, H. I995. Frau. In Reallexikon der Germanischen Altertumskunde 9. Berlin, New York: De Gruyter, 477-508.

Schmidt-Wiegand, R. I99I. Mit Hand und Mund. In Frühmittelalterliche Studien 25, 283-299.

Schmidt-Wiegand, R. I992. Umarmung. In Handwörterbuch zur deutschen Rechtsgeschichte 34, 419-42I.

Schmidt-Wiegand, R. I998. Gebärde. Gebärdensprache im Recht. In Reallexikon der Germanischen Altertumskunde Io. Berlin, New York: De Gruyter, 500-504.

Simek, R. I993. Dictionary of Northern Mythology. (English revised edition of Lexikon der germanischen Mythologie I984. Stuttgart, Alfred Kröner Verlag). Cambridge: Brewer.

Simek, R. 2002. Goddesses, Mothers, Dísir. Iconography and Interpretation of the Female Deity in Scandinavia in the First Millenium. In R. Simek \& W. Heizmann (eds).Mythological Women. Studies in Memory of Lotte Motz (1922-1997). Studia Medievalia Septentrionalia 7. Wien: Fassbaender, 93-I23.

Sjöborg, N.H. I79I. Topographia paroecice Raflunda et monumentorum quae circee sunt. Lund.

Stamsø Munch, G. 2003. Borg as a Pagan Centre. In G. S. Munch et al. (eds). Borg in Lofoten. A Chieftain's Farm in North Norway. Arkeologisk Skriftserie I.Trondheim: Tapir, 253-263.

Steinsland, G. I989. Det hellige bryllup og norrøn kongeideologi. En analyse af hierogami-myten i Skírnismál, Ynglingatal, Háleygjatal og Hyndluljód. Oslo: Solum.

Steinsland, G. I997. Die mythologische Grundlage für die nordische Königsideologie. Germanische Religionsgeschichte. In Ergänzungsband zum Reallexikon der Germanischen Altertumskunde 5. Berlin, New York: De Gruyter, 736-75I 
Stolpe, H. \& Arne, T.J. I912. Graffältet vid Vendel. Stockholm: Kungl. Vitterhets historie och antikvitetsakademien.

Sundqvist, O. 2004. Sakralkönigtum. C. Skandinavische Quellen. In Reallexikon der Germanischen Altertumskunde 26. Berlin, New York: de Gruyter, 279-293.

Watt, M. I992. Die Goldblechfiguren ('guldgubber') aus Sorte Muld, Bornholm. In K. Hauck (ed.). Der historische Horizont der Götterbild-Amulette aus der Übergangsepoche von der Spätantike zum frühen Mittelalter. Abhandlungen der Akademie der Wissenschaften in Göttingen, Philologische-Historische Klasse, Dritte Folge 200. Göttingen: Akademie der Wissenschaften in Göttingen, 195-227.

Watt, M. 2004. The Gold-Figure Foils ("Guldgubbar") from Uppåkra. In L. Larsson (ed.). Continuity for Centuries. A Ceremonial Building and its Context at Uppåkra, Southern Sweden. Uppåkrastudier ıo, Acta Archaeologica Lundensia. Stockholm: Almqvist \& Wiksell, I67-22I.

Watt, M. 2007. Kan man tyde guldgubbernes gestussprog? (Gold foil figures and gesture language). In I. Nordgren (ed.). Kult, guld och makt. Ett tvärvetenskapligt symposium i Götene. Skara: Historieforum Götaland, I33-I48.

Watt, M. 20II. Images of the Female Elite in $6^{\text {th }}-7^{\text {th }}$ Century Scandinavia. In D. Quast (ed.). Weibliche Eliten in der Frühgeschichte. RGZM Tagungen Iо. Mainz: Schnell \& Steiner, 229-250.

Watt, M. 20I5a. A Christian "Fingerprint" on $6^{\text {th }}$ Century South Scandinavian Iconography? In Heizmann \& Oehrl (eds). Bilddenkmäler zur germanischen Götter- und Heldensage. Ergänzungsbände zum Reallexikon der Germanischen Altertumskunde 9I. Berlin, New York: de Gruyter, I 53-1 80.

Watt, M. 20 I 5b. “Christian” Gestures and Fertility Cult(?) Reflected in the Iconography of $6^{\text {th }}$ Century Southern Scandinavia. In C. Rühmann \& V. Brieske (eds). Dying Gods - Religious Beliefs in Northern and Eastern Europe in the Time of Christianisation. 
Neue Studien zur Sachsenforschung. Band 5. Hannover: Niedersächsisches Landesmuseum, I77-I90.

Watt forthcoming. (working title): Sorte Muld. Guldgubberne og Ibskerbygden. In Nordiske Fortidsminder. Købehavn: Kgl. nordiske oldskriftselskab. 


\section{Response}

Olof Sundqvist

Stockholm University

Margrethe Watt is one of the world's leading experts on gold foil figures (Swedish "guldgubbar") with plenty of publications on this topic. ${ }^{\mathrm{I}}$ She has been working with this material for almost thirty years and she knows it in great detail. In the present article she focuses on the relationship between the gold foils and Old Norse mythology.

In what follows I will concentrate on the fourth group of foils, reflecting the concept of "The legally binding marriage". This refers to gold foils with a man and a woman facing each other. Common to all of these foils is some degree of physical contact between the male and the female, ranging from an embrace to a light touch. This motif is known from all three "provinces" (see Watt's text above). Gro Steinsland has connected it with ruler ideology and a hieros gamos between the god Freyr and the giantess Gerðr. ${ }^{2}$ Her suggestion was based on Magnus Olsen's interpretation of the "double-figures" found at Klepp in Rogaland in western Norway as a reflection of the mythical "marriage" between Freyr and Gerðr as it appears in Skirnismál. ${ }^{3}$ According to Snorri Sturluson's Ynglinga saga Ch. Io, this couple were the mythical founders of the Ynglinga dynasty. Their sexual union resulted namely in a son called Fjolnir, who was the first king in this family. ${ }^{4}$ This strange hieros gamos between a god and a giantess thus has, according to Steinsland, ideological implications. She supported her argument with the fact that gold foils of this type often appear at aristocratic settlements, in halls and more precisely in the area of the high-seat.

Watt is sceptical to both Olsen's and Steinsland's mythical-ideological interpretations. Based on an argument originally presented by Rudolf Simek, ${ }^{5}$ she argues that the gestures shown on these gold foils actually represent a formal and legally binding ceremony, the so called mundr-marriage, which is mentioned in legal texts and manuscript illustrations from later centuries, 
such as Sachsenspiegel and the medieval Swedish and Norwegian Provincial Laws from the $13^{\text {th }}$ century or later. They mention and sometimes illustrate the rules for giving hands and touching each other when legally binding couples together in marriage. In this case, Watt accepts that medieval sources can be used when interpreting Merovingian Period iconography. Watt states, however, that she will not attempt to identify the figure-type appearing in this group with named mythological characters, "certainly not Gerðr and Freyr whose union (according to "Germanic law") would be regarded as an unacceptable common law marriage". In Skirnismál it seems as if Freyr took his bride with force and not in a legal way. The union between a god and a giantess could also be regarded as a misalliance against social norms. ${ }^{6}$

According to Watt, the myth about Freyr's courtship and unlawful marriage to the giantess Gerðr does not fit with the body language of "the double figures". Hence, both Watt and Simek ${ }^{7}$ reject the possibility that these foils reflect cultic aspects related to Freyr. To a certain extent I must agree with them in this argument and I accept the idea that the foils may actually represent human couples too. I have, however, also some objections against Watt's (and Simek's) reasoning. When stating that the foils with the "double-figure" relate to the concept of "The legally binding marriage", the interpretation of the gestures and body language is dependent on legal sources written 500 years after the time when the foils were produced. The concept of "The legally binding marriage" used by Watt actually requires that there were laws or at least legal customs which were common in all Scandinavia during the Merovingian Period. "The double figures" appear namely in all three provinces where gold foils have been found, from Borg at Lofoten in the North to GudmeLundeborg on Fyn in the South. In order to understand the body language on these foils, the judicial rituals must have been uniform over this large area and stable over time for more than 500 years. In my opinion, we still cannot rule out that the couple embracing each other refers to a simpler expression of intimacy with no legal implications, or something else.

My second objection concerns Watt's (and Simek's) interpretations of the mythical beings in a more general sense. Should 
we ever expect that the god Freyr and the mythical being Gerðr were conceived in the same way during the $6^{\text {th }}$ or $7^{\text {th }}$ century as in the Eddic poems found in manuscripts from the $\mathrm{I} 3^{\text {th }}$ and $\mathrm{I} 4^{\text {th }}$ centuries written down in Christian contexts? The myths and the conception of mythical beings most likely changed over time. The poem Skirnismál, which contains the myth about Freyr and Gerðr, is usually regarded as a young lay and it has a literary character. ${ }^{8}$ For instance, Daniel Sävborg' states that "Skírnismál should be interpreted as a high medieval poem, composed as pure entertainment by a person conscious of the literary fashion of his time". In a general sense, I agree with this statement, even if I think that it is possible that this "literary account" may be based on an older mythical tradition related to some type of hieros gamos and ruler ideology. It is likely that the union between the god Freyr and his bride (if it existed) had a different mythical context and was conceived in another way during the Merovingian Period and Viking Age compared to the one we may find in Skirnismál, Gylfaginning and Ynglinga saga.

We may actually partly follow this tradition back to Early Viking Age. The information in Ynglinga saga Ch. Io that Freyr and his wife Gerðr had a son called Fjolnir can partly be supported by the $9^{\text {th }}$ century poem Ynglingatal. In this poem it is mentioned that the kinsmen of Fjolnir were regarded as descendants of Freyr. In the stanza about Alrekr and Eiríkr the whole family is called Freys afspringr, 'Freyr's offspring', while Egill is týsóttungr, 'descendant of the god'. The Uppsala king Aðils is described as Freys óttungr, 'Freyr's descendant' and Ingjaldr, finally, is designated goðkynningr, 'of divine descent'. In my opinion the reliable sources thus tell us that the Uppsala family reckoned its origin from Freyr, the blótgoð svía, who was praised as the Ynglingar's particular god. It is harder to identify the mother. The tradition found in Ynglingatal implicitly requires that Freyr had a wife, whoever she was.

There is actually an argument supporting the notion that some foils with the double figures may have represented Freyr and his bride during the Late Iron Age, at least in eastern Scandinavia. The distribution of theophoric place-names in the Lake Mälaren region indicates that the cult of the god Freyr was very important 
in the south-western part of the area, i.e. south Fjädrundaland, south Västmanland and Södermanland. ${ }^{\text {Io }}$ This area corresponds quite well to the places where gold foil figures have been found in this region, i.e. Husby (Glanshammar), Eskilstuna, Ultuna, Helgö, and Svintuna (Bodaviken). The phallic Rällinge statuette and the three phallic figures from Lunda, which most likely represent Freyr, may also be connected to this area. Adam of Bremen thus states in the $\mathrm{II}^{\text {th }}$ century about the image of Freyr in the Uppsalatemple: "His likeness, too, they fashion with an immense phal-

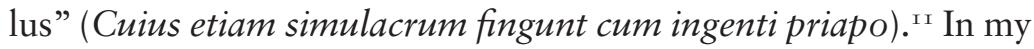
opinion, Steinsland's interpretation of the foils is thus possible, as long as we relate these objects to this geographic area. The mythical wedding on these foils may therefore sometimes be related to Freyr and his bride, perhaps a Merovingian Period conception of Gerðr. Moreover, Adam of Bremen states that sacrifices should be made to Freyr when celebrating wedding: "If plague and famine threaten, a libation is poured to the idol Thor; if war, to Wodan; if marriages are to be celebrated, to Fricco [Freyr]" (Si pestis et fames imminet, Thor ydolo lybatur, si bellum, Wodani, si nuptiae celebrandae sunt, Fricconi). ${ }^{\mathrm{I2}}$ This indicates that Freyr in the $\mathrm{II}^{\text {th }}$ century Lake Mälaren area had a special relationship to marriages. Whether he had that 300 years earlier is, of course, uncertain.

It is possible, however, that the couple on the foils from Trøndelag represented another divine couple. Perhaps the couple on the foils from Mære could be related to Óðinn and Skaði, as suggested by Gro Steinsland, ${ }^{\mathrm{I} 3}$ since these mythical beings, according to Háleygjatal, were regarded as the divine parents of the Lade Earls. One could also relate the couple depicted on the gold foil figures to Porgerðr Hǫlgabrúðr and Holgi, who may have been considered to be the original mythical ancestors of the noble kin from Halogaland. This assumption presupposes that the Lade Earls had some influence on the sanctuary at Mære as early as the Merovingian Period. This idea must be considered somewhat uncertain. If gold foils were still used during the $8^{\text {th }}$ century, this theory is at least possible. It is possible too that in an earlier period there may have been some other noble ruling families in Mære and Trøndelag, who regarded Freyr and his bride or another divine couple as their mythical ancestors. Later 
Óðinn and Skaði were regarded as the mythical parents of the Haleygja kin.

It should be noticed that these figures may have a double function, i.e. to memorize an aristocratic wedding between the ruling couple, and in the same time they could symbolize a divine spousal. I thus agree with Rudolf Simek when he states thus:

Wir können die Funktion der Doppelgubber also als Opfer oder Memorialakt innerhalb einer dynastischen Hochzeit interpretieren, wobei die Identität der dargestellten Personen gleichzeitig als das irdische Fürstenpaar als auch ihrer mythologischen Vorbilder, also eines der Götterpaare wie Thor und Sif oder etwa Odin und Frigg ansehen. ${ }^{\mathrm{I}}$

His next statement is however more uncertain and to a certain extent invalid when seen from the perspective of a historian of religions:

Mit sicherheit auszuschließen sind als Vorbilder einer dynastischen Hochzeit inzestuöse Verbindungen wie Freyr und Freya oder gewaltsam herbeigeführte und unstandesgemäße Liaisons wie die von Freyr und Gerðr. ${ }^{15}$

In the history of religions, it is not odd that a mythical sister and brother, or a mother and son, had a sexual relationship. We meet several incestuous relationships in, for instance, the context of Greek myths. ${ }^{16}$ The negative attitude to the incestuous relationship between Freyr and Freyja in the sources may thus be a consequence of a Christian impact on them. ${ }^{17}$ In my opinion, moreover, we do not have to exclude that the union on the foils was between Freyr and his bride, perhaps the Merovingian Period conception of Gerðr, since this relation could have had another character during that period compared with the one we meet in the high medieval texts.

Even if I do not completely agree with Watt when interpreting the "double-figure", I must underline that her presentation above is probably the most solid and useful we have so far concerning these materials. Her interpretations of the foils are often balanced and convincing, and they are based on a great knowledge. Watt's scholarship is a very important contribution, not only to archaeology, but also to the history of religions. 


\section{Notes}

I. See e.g. Watt I992; 2004; 2007; 20II; 20I5a; 20I5b.

2. See e.g. Steinsland I990; I99I; 2000.

3. Cf. Olsen I909.

4. In Ynglinga saga Ch.ıo, Snorri states thus: "His wife was called Gerðr Gymisdóttir. Their son was called Fjolnir. (Gerðr Gymisdóttir hét kona hans. Sonr peira hét Fjolnir)." This information does not appear elsewhere. Hyndluljóð st. 30 informs us, however, that Gerðr, Gymir's daughter, was married to Freyr (Freyr átti Gerði) and Lokasenna st. 42 mentions thus: "With gold you had Gymir's daughter bought (Gulli keypta léztu Gymis dóttur)”.

5. Simek 2002.

6. Cf. Simek 2002; 20I4:76

7. Simek 2002; 2014 .

8. E.g. von See et al. I997:64-65.

9. Sävborg 2006:339.

Iо. Sundqvist 2016.

I I. Adam of Bremen IV, 26.

I 2. Adam of Bremen IV, 27.

I3. Steinsland I99I.

I4. Simek 20I4:76.

I 5. Simek 20I 4:76.

I6. See e.g. Burkert I98 5:219-220.

I7. This attitude can be seen in late texts such as Ynglinga saga Ch. 4 and Lokasenna st. 32 and 36.

\section{References}

\section{Primary sources}

Adam of Bremen. Magistri Adam Bremensis Gesta Hammaburgensis Ecclesiae Pontificium. Schmeidler, B. I917. Magistri Adam 
Bremensis Gesta Hammaburgensis Ecclesiae Pontificium. Scriptores rerum germanicarum in usum scholarum. Ex Monumentis Germaniae Historicis. Editio Tertia. Hanover, Leipzig.

- Tschan, F. J. 2002 (I959). History of the Archbishops of Hamburg-Bremen. Trans. F. J. Tschan. New York: Columbia University Press.

Edda. Neckel, Gustaf \& Kuhn, Hans. I983 (I9I4). Die Lieder des Codex Regius. Nebst verwandten Denkmälern. Band I. Text. (Ed.) G. Neckel, 5. verbesserte Auflage von H. Kuhn. Heidelberg: Carl Winter Universitätsverlag.

L Larrington, Caroline. 1996. The Poetic Edda. A new translation by Carolyne Larrington. Oxford: Oxford University Press. Hyndlolióð, see Edda.

Lokasenna, see Edda.

Snorri Sturluson, Heimskringla. Bjarni Aðalbjarnarson. I979 (I94I, I945, I95I). Heimskringla. I-III. Íslenzk fornrit XXVI-XXVIII. Reykjavík: Hið Íslenzka Fornritafélag.

- Hollander, L. M. I964. Heimskringla. History of the Kings of Norway. Trans. L. M. Hollander. Austin: University of Texas.

Ynglinga saga, see Snorri Sturluson, Heimskringla.

\section{Secondary literature}

Burkert, W. I98 5. Greek Religion. Orig. title Griechische Religion der archaischen und klassischen Epoche. Trans. J. Raffan. Cambridge: Harvard University Press.

Olsen, M. I909. Fra gammalnorsk myte og kulthus. Maal og minne, I7-36.

See, Klaus von et al. 1997. Edda: Kommentar zu den Liedern der Edda, 2. Heidelberg: Winter.

Simek, Rudolf. 2002. Goddesses, Mothers, Dísir. Iconography and Interpretation of the Female Deity in Scandinavia in the First Millenium. In R. Simek \& W. Heizmann (eds). Mythological 
Women. Studies in Memory of Lotte Motz (1922-1997). Studia Medievalia Septentrionalia 7. Wien: Fassbaender, 93-I23.

Simek, Rudolf. 2014 (2003). Religion und Mythologie der Germanen. Darmstadt.

Steinsland, G. I990. De nordiske gullblekk med parmotiv og norrøn fyrsteideologi. Et tolkningsforslag. In Collegium Medievale I. Vol. 3. Oslo, 73-94.

Steinsland, G. I991. Det hellige bryllup og norrøn kongeideologi. En analyse av hierogami-myten i Skírnismál, Ynglingatal, Háleygjatal og Hyndluljóð. Oslo.

Steinsland, G. 2000. Den hellige kongen. Om religion og herskermakt fra vikingtid til middelalder. Oslo.

Sävborg, Daniel. 2006. Love among Gods and Men. Skírnismál and its Tradition. In Anders Andrén; Kristina Jennbert; Catharina Raudvere (eds.). Old Norse Religion in Long-Term Perspectives. Origins, Changes, and Interactions: An International Conference in Lund, Sweden, June 3-7, 2004. Vägar till Midgård, 8. Lund: Nordic Academic Press.

Watt, M. I992. Die Goldblechfiguren ('guldgubber') aus Sorte Muld, Bornholm. In K. Hauck (ed.). Der historische Horizont der Götterbild-Amulette aus der Übergangsepoche von der Spätantike zum frühen Mittelalter. Abhandlungen der Akademie der Wissenschaften in Göttingen, Philologische-Historische Klasse, Dritte Folge 200. Göttingen: Akademie der Wissenschaften in Göttingen, I95-227.

Watt, M. 2004. The Gold-Figure Foils (Guldgubbar) from Uppåkra. In L. Larsson (ed.). Continuity for Centuries - A Ceremonial Building and its Context at Uppåkra, Southern Sweden. Acta Archaelogica Lundensia series in 80, No. 48. Lund, I67-222.

Watt, M. 2007. Kan man tyde guldgubbernes gestussprog? In I. Nordgren (ed.). Kult guld och makt, ett tvärvetenskapligt symposium i Götene. Göteborg.

Watt, M. 20II. Images of the Female Elite in $6^{\text {th }}-7^{\text {th }}$ Century Scandinavia. In D. Quast (ed.). Weibliche Eliten in der Frühgeschichte. RGZM Tagungen ıo. Mainz: Schnell \& Steiner, 229-250. 
Watt, M. 20I5a. A Christian "Fingerprint" on $6^{\text {th }}$ Century South Scandinavian Iconography? In Heizmann \& Oehrl (eds). Bilddenkmäler zur germanischen Götter- und Heldensage. Ergänzungsbände zum Reallexikon der Germanischen Altertumskunde 9I. Berlin, New York: de Gruyter, I 53-1 80.

Watt, M. 20I 5 b."Christian” Gestures and Fertility Cult(?) Reflected in the Iconography of $6^{\text {th }}$ Century Southern Scandinavia. In C. Rühmann \& V. Brieske (eds). Dying Gods. Religious Beliefs in Northern and Eastern Europe in the Time of Christianisation. Neue Studien zur Sachsenforschung. Band 5. Hannover: Niedersächsisches Landesmuseum, I77-I90. 
